\section{HIGH-STRENGTH FLOWABLE MORTAR REINFORCED BY STEEL FIBER}

\section{ABSTRACT}

An experimental study was conducted on High-Strength Flowable Mortar (HSFM) reinforced at different percentages of steel fiber $(0,0.25,0.5,0.75,1.0,1.25,1.5,1.75$ and $2.0 \%$ as volumetric fractions) to determine the density, compressive strength, static modulus of elasticity and flexural strength. The load-deflection curves under a static flexural load were established, and the flexural toughness indices were obtained in accordance with ASTM C1018. The results indicate that by increasing the fiber content up to $1.75 \%$, the flexural strength and toughness indices are increased. The density, compressive strength and static modulus of elasticity also increased using steel fiber.

\section{KEY WORDS}

- Steel fiber,

- reinforcing material,

- high-strength mortar,

- flowable mortar.

\section{INTRODUCTION}

High-strength concrete or mortar subjected to axial compression is known to be a brittle material with almost no strain-softening behavior. Adding fibers to a plain matrix has little or no effect on its precracking behavior but does substantially enhance its postcracking response, which leads to greatly improved toughness and impact behavior (Al-Oraimi \& Seibi, 1995). Besides, ductility in fiber-reinforced cementitious composites is enhanced because the fibers bridge cracked surfaces and delay the onset of the extension of cracks (Aydin, 2007). Many researchers have conducted investigations to study fiber-reinforced concrete in the past. Shah \& Naaman (1976) conducted tensile strength, flexural strength and compressive strength tests on mortar specimens reinforced with steel and glass fiber and found that the tensile or flexural strength of steel fiber-reinforced mortar was at least two to three times that of plain mortar specimens. Similarly, Nataraja, et al. (1999) observed that the effect on the compressive strength of adding steel fibers to concrete ranges from negligible and sometimes up to $25 \%$, whereas the addition of steel fibers significantly increases the strain capacity and elastic deformation toughness of the concrete matrix by about $75 \%$. Modern concrete can be designed to have a great degree of flowability, which allows the concrete to flow in congested reinforcement areas and fill complicated formwork segregating (Okamura \& Ouchi, 2007; Gang, et al., 2003). Mortar serves as the basis for the properties of flowing concrete, and assessing the properties of flowable mortar is an integral part of the design of flowing concrete, (Domone \& Jin, 1999). On the other hand, the repair mortar applied to concrete is usually hard to compact well; therefore, repair mortar with a high degree of flowability may bring considerable advantages to a narrow mould system (Khayat \& Morin, 2002). The main concern with high- 
strength mortar is increasing the brittleness when increasing the strength; thus it becomes a more acute problem to improve the ductility of High-Strength Flowable Mortar (HSFM) (Zhou, et al., 1994). The experience gained using normal strength fiber-reinforced concrete may be applicable to high-strength flowable mortar, but the effectiveness of fiber reinforcement in high-strength flowable mortar may be different and needs to be investigated (Balendran, et al., 2002). Therefore, the objective of this study is to assess the effects of using steel fiber at different volume fractions in a mix of High-Strength Flowable Mortar (HSFM) and study some properties of this mortar.

\section{MATERIALS AND MIX PROPORTIONS}

\subsection{Materials}

The cement used in the mortar mixtures was ordinary Portland cement type I, a product of Tasek Corporation Berhad. Silica fume from Scancem Materials Sdn. Bhd. was used as a partial replacement of the cement. The chemical compositions of ordinary Portland cement and silica fume are given in Table 1. An amount of $1.8-2.2 \%$ of the superplasticizer (SP) Conplast SP1000 Fosroc Sdn. Bhd. was used in the weight of the binder to enhance the flowability of all the mixes. The fine aggregate used was natural sand with a fineness modulus of 2.86 and a maximum size of less than $5 \mathrm{~mm}$.

Tab. 1 Chemical composition of ordinary Portland cement and silica fume.

\begin{tabular}{|c|c|c|}
\hline \multirow{2}{*}{ Constituent } & $\begin{array}{c}\text { Ordinary Portland } \\
\text { Cement }\end{array}$ & Silica fume \\
\cline { 2 - 3 } & \% by weight & \% by weight \\
\hline Lime $(\mathrm{CaO})$ & 64.64 & 1.0 \\
\hline Silica $\left(\mathrm{SiO}_{2}\right)$ & 21.28 & 90 \\
\hline Alumina $\left(\mathrm{Al}_{2} \mathrm{O}_{3}\right)$ & 5.60 & 1.2 \\
\hline Iron Oxide $\left(\mathrm{Fe}_{2} \mathrm{O}_{3}\right)$ & 3.36 & 2.0 \\
\hline Magnesia $\left(\mathrm{MgO}^{2}\right)$ & 2.06 & 0.6 \\
\hline Sulphur Trioxode $\left(\mathrm{SO}_{3}\right)$ & 2.14 & 0.5 \\
\hline $\mathrm{N}_{2} \mathrm{O}$ & 0.05 & 0.8 \\
\hline $\mathrm{LOI}$ & 0.64 & 2.4 \\
\hline Lime saturation factor & 0.92 & ----- \\
\hline $\mathrm{C}_{3} \mathrm{~S}$ & 52.82 & ----- \\
\hline $\mathrm{C}_{2} \mathrm{~S}$ & 21.45 & ---- \\
\hline $\mathrm{C}_{3} \mathrm{~A}$ & 9.16 & ---- \\
\hline $\mathrm{C}_{4} \mathrm{AF}$ & 10.2 & ----- \\
\hline
\end{tabular}

Tab. 2 Characteristics of Steel fiber.

\begin{tabular}{|c|c|}
\hline Fiber Properties & Quantity \\
\hline Average fiber length, $\mathrm{mm}$ & 30 \\
\hline Average fiber diameter, $\mathrm{mm}$ & 0.56 \\
\hline (I/d) aspect ratio & 54 \\
\hline Tensile strength $(\mathrm{MPa})$ & $>1100$ \\
\hline Ultimate elongation\% & $<2$ \\
\hline Specific gravity & 7.85 \\
\hline
\end{tabular}

The steel fiber used in this study is hook ends low carbon cold drawn produced by Hunan Sunshine Steel Fiber Co. Ltd, and its characteristics are shown in Table 2.

\subsection{Mix proportions}

The design of the mortar's composition is given in Table 3. Nine mixes were evaluated. In all the mixes the amounts of cement, silica fume, sand and free water were kept constant. The waterbinder (cement+ silica fume) ratio was 0.43 , and the silica fume replacement was $10 \%$. The amount of superplasticizer was changed from $1.8 \%$ to $2.2 \%$ by the weight of the binder materials, content to maintain the appropriate flowability for all the mixes. The control mix (M0) was designed according to the absolute volume method given by the American Concrete Institute (ACI). Steel fiber at volumetric fractions of $0.25,0.5,0.75,1.0,1.25 .1 .5,1.75$ and $2.0 \%$ of the mixes was used in preparing the M1-M8 mixes.

\section{TEST METHODS}

Three $50 \mathrm{~mm}$ cube samples were prepared for each mix to test the density and compressive strength of the mortar after curing them in water until the time of the test. The flow test for the mixes was performed according to EN 1015-3. The mixes were designed for a flow of $150 \mathrm{~mm} \pm 10 \mathrm{~mm}$. The cube specimens were left in the molds for 24 hours at $20{ }^{\circ} \mathrm{C}$ after casting. After demolding, the specimens were kept in plain water until the time of the test. The test for the saturated surface dry density of the specimens at the time of the test was adopted and implemented according to EN 1015-6. The test for compressive strength was performed directly after the density test according to EN 1015-11 at each stage of the test. The static modulus of elasticity test was achieved using $150 \times 300 \mathrm{~mm}$ cylinders according to ASTM C469. Besides, three $40 \times 40 \times$ $160 \mathrm{~mm}$ prismatic steel molds were used to prepare the specimens for the flexural strength test according to EN 1015-11, and the toughness indices were determined according to ASTM C1018. 


\section{SIOYALYSOUSSILI

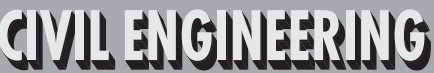

2011/3 PAGES $10-16$

Tab. 3 Mortar Mixes proportions.

\begin{tabular}{|c|c|c|c|c|c|c|c|c|}
\hline Index & $\begin{array}{c}\text { Cement } \\
\text { Kg. } \mathbf{m}^{-3}\end{array}$ & $\begin{array}{c}\text { Silica fume } \\
\mathbf{K g} \cdot \mathbf{m}^{-\mathbf{3}}\end{array}$ & $\begin{array}{c}\text { Water } \\
\mathbf{K g} \cdot \mathbf{m}^{-3}\end{array}$ & $\begin{array}{c}\text { SP } \\
\mathbf{\%}\end{array}$ & $\begin{array}{c}\text { Sand } \\
\mathbf{K g}^{-\mathbf{m}^{-3}}\end{array}$ & $\mathbf{W}+\mathbf{S P} / \mathbf{B}$ & $\begin{array}{c}\text { Steel Fiber } \\
\mathbf{\%}\end{array}$ & $\begin{array}{c}\text { Flow } \\
\mathbf{\%}\end{array}$ \\
\hline M0 & 550 & 55 & 260 & 1.8 & 1410 & 0.43 & 0 & 160 \\
\hline M1 & 550 & 55 & 260 & 1.8 & 1410 & 0.43 & 0.25 & 155 \\
\hline M2 & 550 & 55 & 260 & 1.8 & 1410 & 0.43 & 0.50 & 150 \\
\hline M3 & 550 & 55 & 260 & 1.8 & 1410 & 0.43 & 0.75 & 150 \\
\hline M4 & 550 & 55 & 260 & 2.0 & 1410 & 0.43 & 1.00 & 145 \\
\hline M5 & 550 & 55 & 260 & 2.0 & 1410 & 0.43 & 1.25 & 145 \\
\hline M6 & 550 & 55 & 260 & 2.0 & 1410 & 0.43 & 1.50 & 140 \\
\hline M7 & 550 & 55 & 260 & 2.2 & 1410 & 0.43 & 1.75 & 140 \\
\hline M8 & 550 & 55 & 260 & 2.2 & 1410 & 0.43 & 2.00 & 140 \\
\hline
\end{tabular}

\section{RESULTS AND DISCUSSION}

\subsection{Saturated surface dry density}

Table 4 shows the results of the saturated surface dry density for all the mixes. The saturated surface dry density at 7 and 28 days for the different mixes show that there is a rise in the density as the volume fraction of the steel fiber is increased, which is due to the specific gravity of the fiber, which increases the overall density of the mortar as shown in Figure 1.

\subsection{Compressive strength}

From Table 4 and Figure 2, it can be concluded that the increase in the volume fraction of the steel fiber in the mix increases the compressive strength due to the improvement in the mechanical bond strength between the steel fibers and mortar, where the fibers provide the ability to delay formation of micro-cracks and arrest their propagation afterwards up to a certain extent of the fibers' volume fraction (Mustafa \& Yaman, 2007, Burak et al., 2007). The percentage

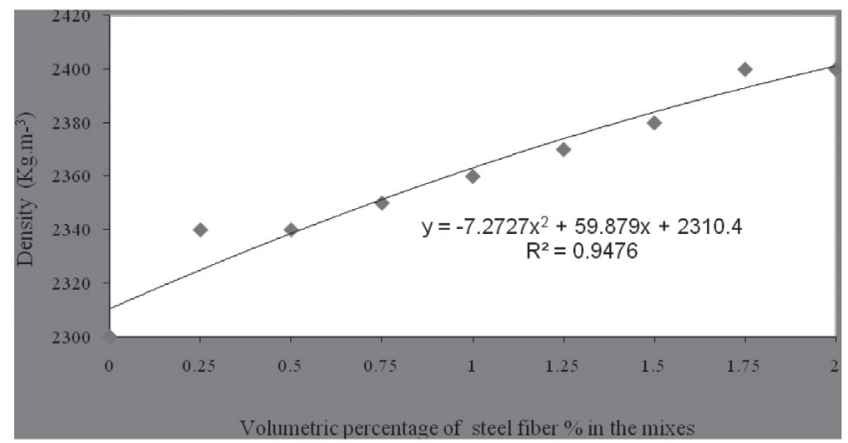

Fig. 1 Relation between fiber content with saturated surface dry density at 28 days.

Tab. 4 Mechanical Properties of Mortar Mixes

\begin{tabular}{|c|c|c|c|c|c|c|}
\hline Index & $\begin{array}{c}\text { Steel Fiber } \\
\%\end{array}$ & $\begin{array}{l}\text { Density } \\
\text { Kg.m }{ }^{-3} \\
\text { (7days) }\end{array}$ & $\begin{array}{l}\text { Density } \\
\text { Kg.m-3 } \\
\text { (28days) }\end{array}$ & $\begin{array}{c}\text { Compressive } \\
\text { strength (MPa) } \\
\text { (7days) }\end{array}$ & $\begin{array}{c}\text { Compressive } \\
\text { strength (MPa) } \\
\text { (28days) }\end{array}$ & $\begin{array}{l}\text { Static modulus } \\
\text { of elasticity } \\
\text { (GPa) (28 days) }\end{array}$ \\
\hline M0 & 0 & 2280 & 2300 & 43.9 & 55.3 & 33.1 \\
\hline M1 & 0.25 & 2310 & 2340 & 45.6 & 57.2 & 35.4 \\
\hline M2 & 0.50 & 2320 & 2340 & 46.8 & 58.9 & 37.8 \\
\hline M3 & 0.75 & 2335 & 2350 & 47.9 & 59.8 & 39.8 \\
\hline M4 & 1.00 & 2340 & 2360 & 49.8 & 60.9 & 41.1 \\
\hline M5 & 1.25 & 2355 & 2370 & 50.7 & 63.1 & 43 \\
\hline M6 & 1.50 & 2365 & 2380 & 48.3 & 59.8 & 44.1 \\
\hline M7 & 1.75 & 2380 & 2400 & 46.1 & 57.1 & 44.9 \\
\hline M8 & 2.00 & 2385 & 2400 & 44.2 & 55.7 & 46.1 \\
\hline
\end{tabular}


increase in compressive strength by using $1.25 \%$ of the steel fiber in the HSFM was about $14 \%$. The comparison between the control mortar mix (M0) and the mix with the highest volume fraction of steel fiber (2\%) used in this study (M8) shows that there is no enhancement of the compressive strength, which is mainly due to the non-homogeneous distribution of the fibers within the mortar mix, which causes a drop in the compressive strength (Markovic, et al., 2003).

The effect of steel fiber with each increase in density and compressive strength (as shown in Figure 2) illustrates that at volume fractions of $1.25 \%$ or less, the compatibility of the increments for density and compressive strength related to the inclusion of steel fiber can be noted.

\subsection{Static modulus of elasticity}

The results of the static modulus of elasticity test are presented in Table 4. It can be concluded that the static modulus of elasticity increases with the volume fraction of steel fiber as shown in

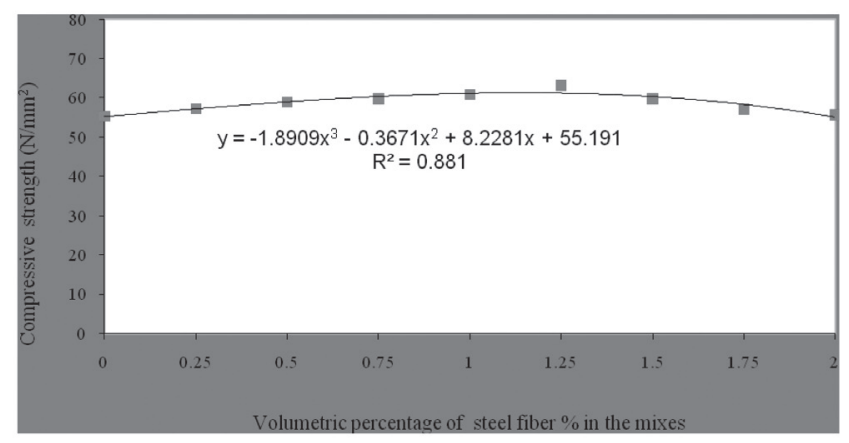

Fig. 2 Relation between fiber content with saturated surface dry density at 28 days.

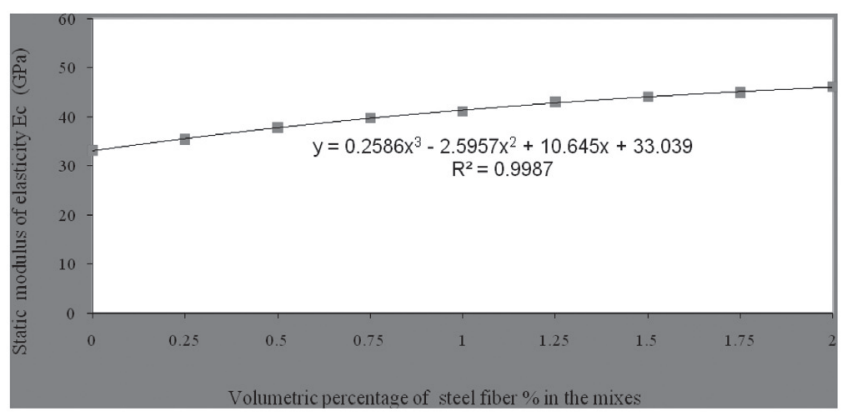

Fig. 3 Relation between fiber content and static modulus of elasticity (Ec) at 28 days.

Figure 3. The static modulus of elasticity is increased by about $39 \%$ when using $2 \%$ of the steel fiber as a volumetric fraction.

This is attributed to the high elastic modulus of the elasticity of the steel fibers, which enhances the elastic deformation capacity of the mortar mixes with the inclusion of steel fibres (Nataraja et al., 1999).

\subsection{Flexural strength}

The flexural strength of the high-strength flowable mortar mixes is shown in Table 5 and Figure 4. An inspection of Figure 3 indicates that a linear relationship exists between the flexural strength and the steel fibers' volume fraction. The increase in the flexural strength of the mix containing a $1.75 \%$ volumetric fraction of steel fiber is $42 \%$ higher than the control mix, which may be due to the better compaction and homogeneity of the fiber distribution in HSFM. It can also be noted that the use of more than $1.75 \%$ of steel fiber slightly decreases the improvement in flexural strength, which

Tab. 5 Flexural \& Toughness Indices for Mortar Mixes.

\begin{tabular}{|c|c|c|c|c|c|c|c|}
\hline Index & $\begin{array}{c}\text { Steel fiber } \\
\text { \% }\end{array}$ & $\begin{array}{c}\text { Flexural } \\
\text { strength } \\
\text { (MPa) (7days) }\end{array}$ & $\begin{array}{c}\text { Flexural } \\
\text { strength (MPa) } \\
\text { (28days) }\end{array}$ & $\begin{array}{c}\text { Toughness } \\
\text { Index (I 5) } \\
\text { (7days) }\end{array}$ & $\begin{array}{c}\text { Toughness } \\
\text { Index (I 5) } \\
\text { (28 days) }\end{array}$ & $\begin{array}{c}\text { Toughness } \\
\text { Index (I 10) } \\
\text { (7days) }\end{array}$ & $\begin{array}{c}\text { Toughness } \\
\text { Index (I 10) } \\
\text { (28 days) }\end{array}$ \\
\hline M0 & 0 & 7.26 & 8.44 & 1 & 1 & 1 & 1 \\
\hline M1 & 0.25 & 7.68 & 8.72 & 1 & 1 & 1 & 1 \\
\hline M2 & 0.50 & 7.96 & 9.49 & 3.35 & 3.64 & 4.95 & 5.42 \\
\hline M3 & 0.75 & 10.17 & 11.65 & 3.45 & 3.85 & 5.25 & 5.93 \\
\hline M4 & 1.00 & 10.43 & 13.25 & 3.89 & 4.10 & 5.68 & 6.16 \\
\hline M5 & 1.25 & 10.85 & 13.52 & 4.12 & 4.28 & 6.38 & 6.73 \\
\hline M6 & 1.50 & 11.27 & 14.28 & 4.75 & 5.10 & 7.52 & 7.93 \\
\hline M7 & 1.75 & 14.74 & 17.1 & 4.95 & 5.35 & 7.93 & 8.45 \\
\hline M8 & 2.00 & 12.1 & 15.9 & 4.65 & 5.05 & 7.78 & 8.22 \\
\hline
\end{tabular}




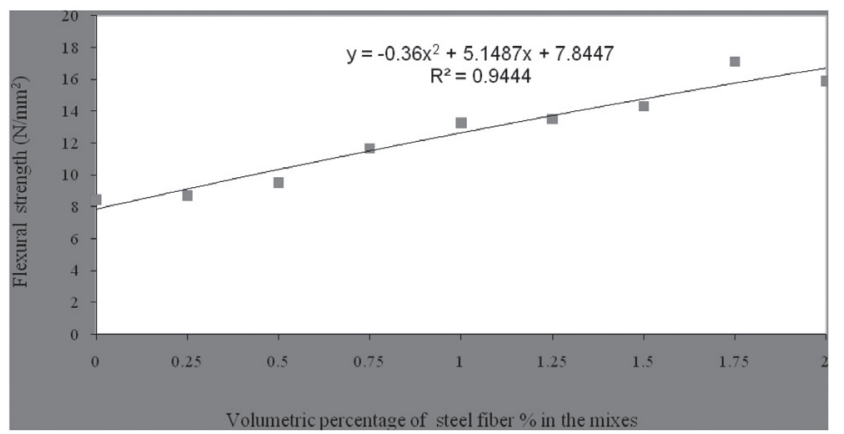

Fig. 4 Relation between fiber content and flexural strength at 28 days.

may be due to the physical difficulties in providing a homogenous distribution of the fibers within the mortar mix (Markovic, et al., 2003).

\subsection{Toughness Indices}

The Toughness indices can be determined according to ASTM C1018. The I5 and I10 indices can be calculated from this test as the ratio of the area under the load deflection curve up to 3 and 5.5 times the first crack deflection, divided by the area up to the first crack deflection respectively as shown in Figure 5. Table 5 summarizes the results of the I5 \& I10 indices for 7 and 28-day specimens. It can be observed that fiber fractions of more than $0.5 \%$ have a clear effect on the toughness indices, which increase as the fiber fraction also increases. This can be attributed to the ability of the fibers to arrest cracks at both the micro and macro levels. At the micro level, the fibers inhibit the initiation of cracks, whereas at the macro level, the fibers provide effective bridging and impart sources of toughness and ductility

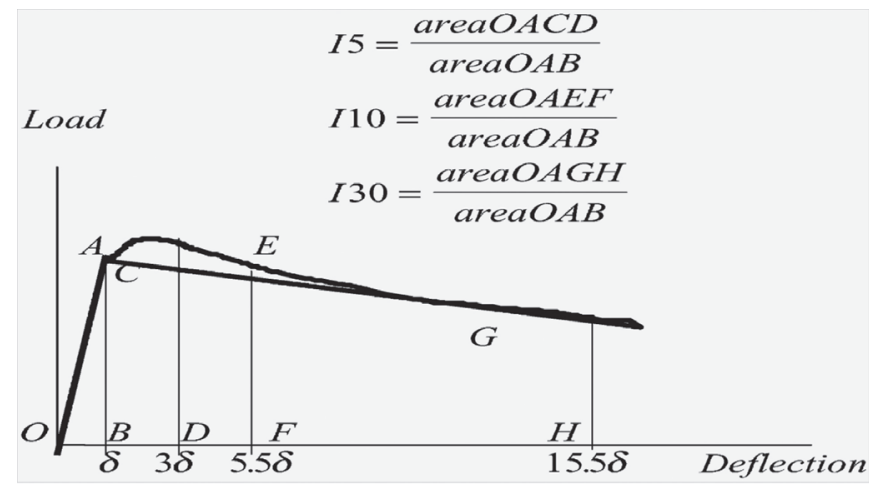

Fig. 5 Toughness indices according to the testing method ASTM C1018.

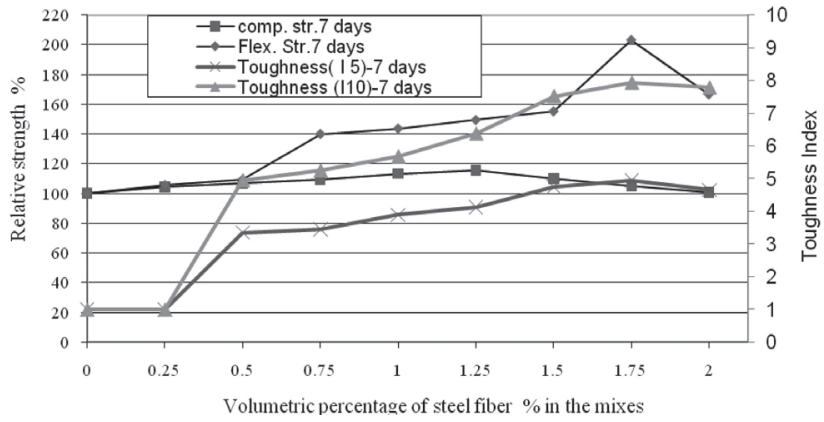

Fig. 6 Influence of fiber content at 7 days with relative strength and toughness indices.

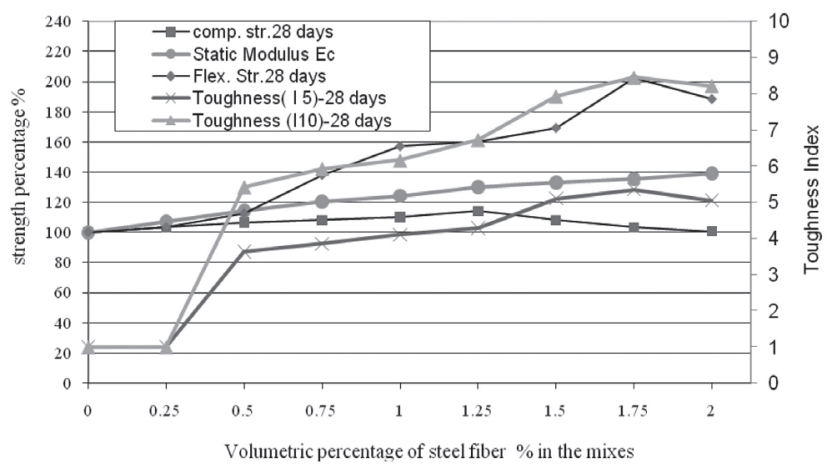

Fig. 7 Influence of fiber content at 28 days with relative strength and toughness indices.

(Balaguru \& Shah, 1992; Banthia \& Sappakittipakorn, 2007). This has also been determined by other researchers (Mohammadi, et al., 2008), whereas the flexural toughness can be increased as the fiber volume fraction increases for a certain aspect ratio. However, the use of $1.75 \%$ steel fiber can be considered as the most appropriate percentage to be employed in HSFM for the toughness indices. Figures 6 and 7 show the effects of using different volume fractions of steel fiber after 7 and 28 days of normal water curing.

\section{CONCLUSIONS}

This paper describes the results of an experimental study performed on high-strength flowable mortar reinforced with various volume fractions of steel fiber. The major findings of this study are:

1. The use of steel fiber at small volume fractions $(0.5 \%$ volume fraction) has clear effects on the properties of high-strength flowable mortar. 
2. The compressive strength results show that the use of the steel fiber increases the compressive strength and that the best improvement is obtained when the steel fiber is $1.25 \%$ of the mortar mix. This is due to the mechanical bond between the cement paste and the steel fiber.

3. The static modulus of elasticity of the flowable mortar increases with the inclusion of steel fiber. The use of $2 \%$ steel fiber in the mortar mix increases the Ec by about $39 \%$.

4. The flexural strength results show that there is a compatible increase in flexural strength by increasing the fiber content. The use of $1.75 \%$ steel fiber as a volumetric fraction gives the highest increase, but beyond this percentage there is a slight decrease in this improvement.
5. The toughness indices results illustrate that the inclusion of steel fiber leads to significant improvements in the ductility and the absorption capacity as the volume fraction of the steel fiber is increased.

\section{ACKNOWLEDGEMENT}

The work described in this paper was supported by a grant from Universiti Sains Malaysia (USM). This support is gratefully acknowledged. This work represents part of the $\mathrm{PhD}$ work of the second author.

\section{REFERENCES}

[8] Balendran, R.V. , Zhou, F.P. , Nadeem, A. \& Leung, A.Y.: Influence of steel fibers on strength and ductility of normal and lightweight high -strength concrete. Building \& Environment, 37, 2007, pp.1361-67.

[9] BS 1881: Part 114: Methods for determination of density of hardened concrete. British Standard, 1983

[10] Burak, F., Turkel, S. \& Altuntas, Y.: Effects of steel fiber reinforcement on surface wear resistance on self compacting repair mortar. Cem. \& Conc. Comp.; 29, 2007, pp.391-396.

[11] Domene, P. L. \& Jine, J.: Properties of mortar for self-compacting concrete. Proceedings of the 1st international RILEM symposium on self-compacting concrete,1999, pp. 109-20.

[12] EN 1015-6: EUROPEAN STANDARD. EN 1015-6, Determination of bulk density of fresh mortar. 1998

[13] EN 1015-11: EUROPEAN STANDARD. EN 1015-11, Methods of test for mortar for masonry: Part 11: Determination of flexure and compressive strength of hardened mortar. 1999.

[14] EN 1015-3: EUROPEAN STANDARD. EN 1015-3, Methods of test for mortar for masonry: Part 3: Determination of consistency of fresh mortar (by flow table) 1999.

[15] Gang, L., Wang, K \& ,Rudolphi, T.J.: Modeling reheological behavior of highly flowable mortar using concepts of particle and fluid mechanics. Cem. \& Conc. Comp.; 30, 2008, pp.1-12. 


\section{REFERENCES}

[16] Khayat, KH , Morin, R.: Performance of self-consolidating concrete used to repair parapet wall in Montreal. Proceedings of the first North American conference on the design and use of self-consolidating concrete, 2002, pp 475-481.

[17] Markovic, I, Walraven, J.C \& Van, M. J.: Self compacting hybrid fiber concrete-mix design, workability and mechanical properties. Proceedings of third international symposium on self-compacting concrete, 2003, pp.763-775.

[18] Mohammadi, Y. Singh, S. P. \& Kaushik, S. K.: Properties of steel fibrous concrete containing mixed fibers in fresh and hardened state. Construction \& Building Materials, 2008, 22, pp.956-965.

[19] Mustafa, S. \& Yaman, O. I.: Hybrid fiber reinforced self compacting concrete with a high volume coarse fly ash. Construction \& Building Materials; 21, 2007, pp. 150156.

[20] Nataraja, M. C, Dhang, N. \& Gupta, A. P.: Stress-strain curves for steel fiber reinforced concrete under compression. Cement \& Concrete Composite; 21, 1999, pp. 383-390.

[21] Neville, A.M: Properties of concrete. Fourth and Final edition, 1995.

[22] Okamura, H. \& Ouchi, M.: Self compacting concrete. J. Adv. Concr Technol,1(1), 2003, pp.1-15.

[23] Shah, S. P. \& Naaman, A. E.:Mechanical properties of glass and steel fiber reinforced mortar. ACI Journal; 73(1), 1976, pp.50-53.

[24] Steffen, G. \& Joost, C. W.: Parameter study on the influence of steel fibers and coarse aggregate content on the fresh properties of self compacting concrete. Cement \& Concrete Research; 31, 2001, pp.1793-1798. .

[25] Zhou, F. P., Barr, B. I. G. \& Lydon, F. D.: Fracture mechanical properties of high strength concrete with varying silica fume content and aggregates. Cement \&Concrete Research, 25(3), 1994, pp. 543-52. 